\title{
Confronting Barriers to the Participation of Bedouin-Arab Women in Israeli Higher Education
}

\author{
Ismael Abu-Saad ${ }^{1}$, Tamar Horowitz ${ }^{1}$, Kathleen Abu-Saad ${ }^{2}$ \\ Ben-Gurion University of the Negev ${ }^{1}$ \\ Gertner Institute for Epidemiology ${ }^{2}$ \\ Israel
}

\begin{abstract}
The Negev Bedouin Arabs are a part of the indigenous Palestinian Arab minority in Israel who historically derived their livelihood from herding and seasonal agriculture. Subsequently they underwent a rapid urbanization process, which entailed the loss of their traditional economy. These changes required a re-making of the Bedouin woman's social, educational and economic role in the life of the community. We explored Bedouin women's experiences in mainstream higher education. The study findings indicated that Bedouin Arab women in higher education demonstrated resilience and agency as participants in modernizing Bedouin traditions, and indigenizing 'Western-style' modernity. Despite the myriad of challenges it presented, they experienced mainstream higher education as an essential avenue for their personal and communal development.
\end{abstract}

\section{Introduction}

The Negev Bedouin are among the indigenous Palestinian Arabs who remained in Israel in the aftermath of the war of 1948. Traditionally, they inhabited the Negev Desert and derived their livelihood from animal husbandry and seasonal agriculture. Subsequently they underwent a rapid, government-planned urbanization process, which entailed the loss of their lands and traditional economy. Today, they are a minority that is systematically being underdeveloped, within the context of a high-income, developed state. They have the lowest education levels, lowest incomes, and highest unemployment rates in the country [1]. The provision of poor-quality educational services, which are distributed in a manner that disproportionately disadvantages Bedouin girls, ensures that the Bedouin continue to lag behind [2].

One of the most detrimental effects of the governmental land expropriation and urbanization of the Bedouin was its dissolution of the productive role of women in the household economy. These changes required a re-making of the Bedouin woman's social, educational and economic role in the community [3].
Since higher education is now critical for integration into Israel's modern economy, we explored Bedouin women's experiences of engagement in mainstream higher education as a means to individual and communal empowerment.

\section{Theoretical Background}

Gender roles in the Bedouin community have been impacted by the rapid and radical change they underwent. Traditionally, females dwelt primarily within the world of the extended family, and made a very important contribution to the household economy (i.e. herding; milking and processing milk products; making the animal hair and wool into carpets, tents, mattresses and pillows; harvesting crops; etc.). They were also considered the "bearers of the family honor", and thus, their families preferred not to risk their reputations by allowing girls to travel alone and mix with males from other tribes. Therefore, there was much more reluctance among the Bedouin over sending their daughters to school than over sending their sons to school, especially when schools were far away $[4,5]$.

A significant factor that spurred the development of formal education in the Bedouin community in general, and for girls in particular, was that following the War of 1967, the Bedouin were able to visit their relatives and tribesmen in the West Bank and Gaza Strip for the first time since 1948. The Bedouin who had remained in Israel found that many of their counterparts in the Occupied Territories (the West Bank and the Gaza Strip) were educated and had become teachers, doctors, lawyers, etc.; while they for the most part had only had limited access to education, and the vast majority of them remained illiterate $[4,6]$. In addition, women as well as men obtained education in the Occupied Territories, while few if any females in the Negev had received education. Intermarriage between these two previously separated segments of the Bedouin community resulted in educated women from the West Bank and Gaza Strip coming to live in the Negev. These contacts had an impact on the dynamics of the Negev Bedouin community and led 
them to send their children, girls and boys, to school in greater numbers [4], [5].

A study was conducted in 1991-92, in which over 300 Bedouin mothers from planned towns and unrecognized villages - $90 \%$ of whom had no formal education themselves - were asked about their aspirations for their children's education (Abu-Saad et al, 1998). Ninety eight percent (98\%) of the mothers said that they would like to see their sons finish high school and $81 \%$ would like to see their daughters finish high school (though about $20 \%$ of these acknowledged the existence of family or financial barriers to realizing their aspirations). In addition, $91 \%$ of mothers hoped that their sons would obtain higher education, as compared to $72 \%$ who hoped that their daughters would obtain higher education. Among the mothers who had aspirations for their children's higher education, 6\% did not expect to see their aspirations fulfilled because of financial barriers, and $12 \%$ did not expect to see their aspirations fulfilled for their daughters because the extended family did not permit girls to obtain higher education [5].

The mothers were also asked about their occupational aspirations for their children. Many of the mothers' aspirations were non-specific (41\% for sons and $32 \%$ for daughters). However, $44 \%$ of mothers hoped to see their sons in high status, whitecollar professions such as medicine, law, and engineering. Thirteen percent (13\%) of mothers held the same aspirations for their daughters, while $28 \%$ said they would like to see their daughters become teachers. Only $9 \%$ of mothers said they would like to see their sons become teachers. Several mothers commented that the professions their sons and daughters entered would depend upon how well they were doing academically. Interestingly, there were no significant differences between the aspirations of mothers who lived in the planned towns and those who lived in unrecognized villages for their sons' and daughters' high school and higher education, or their future occupations [5].

In the late 1990's two major factors led to growth in the numbers of young Bedouin women who were completing high school and attending institutions of higher education. The first was the growth of the influence of the Islamic movement in the Bedouin community. Since Islamic teachings stress the importance of obtaining an education, for both males and females, young women were able to use this religious support to overcome the more conservative Bedouin traditions that restricted women's movement outside the environs of the extended family. The second factor was the establishment of the Center for Bedouin Studies and Development at Ben-Gurion University in 1997. It provided a special, but shortlived, intervention offering female Bedouin students full tuition and academic support for 3-4 years. This project had a positive impact on the community, in terms of the students providing a role model of university-educated Bedouin women.

Throughout Arab society, there are a number of factors that have affected the educational and general status of females, among which are Islam and cultural traditions. We will provide a brief general overview of how these factors have impacted female education.

\subsection{Research on Women, Islam and Tradition}

The role of women in Muslim society has been the subject of extensive research in the last four decades. Until recently, much of this writing has implicitly or explicitly focused on the subordinate status of women in a rigidly segregated social system [8,9]. Women are portrayed as helpless, passive victims, whose very identity, status, and existence are dependent on their male kin [9]. These stereotypes are derived largely from images of women in the Middle East and are generalized arbitrarily to Muslim and Arab women worldwide [10,11].

In contrast, Muslim scholars have argued that, from an historical perspective, Islam actually improved the condition of women, and its proponents assert that a return to the true precepts of Islam, combined with improvements in education, legal, and social rights, would accord women their proper position in Muslim society. The Qur'an and Sunnah institutionalize gender equality and equity in Islam and the rights, roles, responsibilities, and opportunities of women.

Vertical or discriminatory gender division with regard to social and human rights is forbidden in the Qur'an [12]. According to Badawi [13] Islamic law clearly establishes a woman's rights to her own money, inheritance, real estate, and other property, regardless of whether she is married or single. The Qur'an legitimizes women's right to access and control over their own economic resources, even within the family: "Unto men [of the family] belongs a share of that which parents and near kindred leave, and unto women, a share of that which parents and near kindred leave, whether it be a little or much - a determinate share"[14].

With regard to education, female children and adolescents have the same right and responsibility to seek knowledge as do their male counterparts. The Prophet Muhammad said, "Seeking knowledge is mandatory for every Muslim.” [12].

Thus, according to Islam, knowledge and education are clearly essential, and indeed, mandatory, in Islam for both males and females. Rights and opportunities are conferred equally regarding the social, political, economic, and spiritual institutions of Islamic ideology. Badawi [13] asserted that justice was genderless in Islam.

However, in most modern Muslim societies, women do not fully enjoy these rights. This gap between the reality and the ideal is due to the mixing 
of Islamic ideals with the incompatible pre-existing cultural traditions that construct women's status in these societies. It is this conflict between the 'real' and the 'ideal' in social values that defines the gap between Islamic ideals and realities of Muslim women in society [12], [15], [16]. Thus, numerous scholars have argued that women in Muslim countries require fundamental shifts of economic, social, and political policies. Greater effort is needed to align societal orientations on equity and opportunity to the more inclusive and equitable institutions of Islamic ideology. Promoting female education, in which significant progress has been made throughout the developing world - including Muslim countries - will enable and empower Muslim women to be active participants in this process [16], [17], [15].

\section{Objectives and methods}

The present study focuses on the academic, social and political experiences, attitudes, and perceptions of young Bedouin women studying at Ben-Gurion University of the Negev, the main regional university in the Negev. Since both quantitative and qualitative methods were used to explore these issues, the study was carried out in two phases. In the first phase, a selfadministered, structured questionnaire was constructed that probed issues of academic and social expectations and experiences at the university; general aspirations, achievement, motivation and life goals; and, attitudes toward modernity, religiosity, citizenship, and civic and national identity.

\section{Findings}

Questionnaires were completed by 59 of the 98 students to whom they were distributed (response rate: $60 \%)$. In-depth interviews were conducted with 8 students. Pseudonyms are used in reporting the results to protect the confidentiality of the interviewees. The results of the major themes explored quantitatively are summarized, and material from the in-depth interviews is used as the primary tool for interpreting Bedouin female students' experience of higher education, and its meaning for their own lives and the life of their community.

\subsection{Academic experience and stereotypes}

Bedouin women's academic experience was permeated with struggle on myriad levels, including: getting admitted to one's field of choice; adjusting academically and socially; developing essential functional skills in Hebrew (second language) and English (third language); and overcoming logistic and financial barriers.
The female Bedouin students surveyed were asked about their academic experience in the first semester. The vast majority (83\%) felt that studying at the university was a completely different and much more challenging experience than studying at high school had been. Many (45\%) felt they had to cope with difficult materials without enough support, 53\% thought that their study load was too heavy, and $63 \%$ felt great pressure to get high grades. Only 30\% thought that the academic assistance they received through the Dean of Student's office was adequate, while an even lower proportion (22\%) felt that their professors understood their needs.

The in-depth interview shed further light on the "immense psychological adjustment", as one interviewee put it, that attending university required:

Sahar - I found it very overwhelming [when I began studying at the university]; it was a very, very difficult transition to make. I was used to going just from school to home, and that was practically my whole world. Attending the university required an immense psychological adjustment. Suddenly we were thrown into a new society that had a different language, and different norms and values as well. I even felt alienated from the other Arab students I saw, and found it hard to adjust to their behavior.

My academic adjustment is affected by a lot of problems and pressures.

I sit in class and attend the lectures, but sometimes I feel that my brain isn't following the lecturer at all. I never had that problem in high school. Sometimes, I feel so far away from the other students and the lecturer; I feel like an outsider, like someone who doesn't belong, and this affects my concentration.

Yet, I came from the desert, and this has taught me how to be patient, and how to think. I'm not a person to give up easily.

Interestingly, Sahar found that she could draw upon resources she had developed in her home environment - the patience and endurance she had learned in the desert - to help her make the adjustment to the largely foreign environment of the university.

Several of the women spoke about the difficulty of suddenly having to function solely and completely in their second language (Hebrew). They highlighted the stressfulness of this adjustment, in light of their poor academic preparation and lack of prior functional experience in Hebrew. Fatmah discussed how the language difficulties encountered by minority students at the universities created not only academic, but also psychological, pressure:

Fatmah - My first semester, I took Research Methodology, and at the beginning, I didn't understand a single word the professor said. This made me very scared and pressured. It's better now, but to this day, I don't understand everything in the lecture. 
While many of the interviewees shared similar experiences, they also described how their academic skills improved and the psychological pressures decreased over time:

Mona - Now [3rd year] I'm much better adjusted to the university environment. I raise my hand in the middle of a lecture if I don't understand something or didn't catch it, and I ask the professor to repeat it. I also go to the professors with my questions during their office hours.

The survey, which was administered toward the end of the academic year, tends to confirm the notion that the female Bedouin students managed to adjust academically over time and to develop competence in essential academic skills. The percentage of women who were confident about their abilities to express themselves clearly orally and in writing, and to succinctly summarize reading materials, ranged from $43 \%$ to $48 \%$, while about one third acknowledged feeling very embarrassed if they were called upon to speak in class. English remained the greatest problem for them, with $59 \%$ feeling uncomfortable about having to read English texts, and only 21\% expressing confidence about their ability to understand articles and books written in English (see Figure 1).

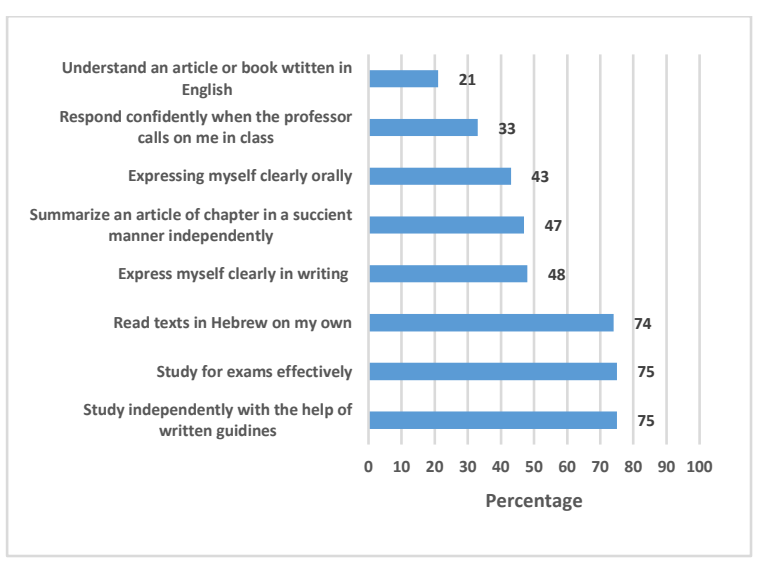

Figure 1: Percentage of Female Bedouin University Students Who Were Confident in Their Abilities to:

Sahar, for example, was acutely aware of the inadequacy of her high school preparation, particularly in the English language, and of its importance to academic success at the university:

I also had problems because of my level of English. I have a very poor background in English, which I think is pretty typical for the students who come out of Arab high schools, because we have a very hard time getting good quality English high school teachers. In my high school, teachers would come and go, often without even finishing a whole year. When I was in the 12th grade, our class didn't have an English teacher for most of the year. Toward the end of the year, we finally got a good teacher, but by then it was too late to make up all the time we had lost. At the university, English is essential to our studies, and I found this to be true especially in Chemistry. Some of our textbooks are in Hebrew, but these books are more like auxiliary texts, and they're not on the same level as the English textbooks, which really form the basis for our studies.

In addition to the academic challenges, the female Bedouin university students also had to confront majority stereotypes of the "the Bedouin woman". One student described her experience as follows:

Yasmin - Jews are given the idea, even at home, that the only thing Bedouin girls know how to do is to herd sheep. They... are weak and will always be weak. It seems to me that many Jewish students are not happy when they look around the lecture hall and see that half of the classroom is filled by Bedouin women. This doesn't fit the stereotype, and they can't figure out what's going on.

According to Yasmin, the negative stereotypes of the Jewish students presented a barrier to developing relationships with them, as they tended to relate to their stereotype of 'a Bedouin woman' rather than relating to her. However, she also felt that she had succeeded in breaking through and altering their stereotypes in some cases, because she insisted upon encountering them as a whole person, and not an one dimensional stereotype.

\subsection{Bedouin traditions and higher education}

The role of Bedouin traditions in shaping women's higher educational opportunities was neither uniform nor static, but was rather undergoing a process of change to respond to the changing socio-economic realities of life. With regard to family support, $72 \%$ of the students surveyed reported that they received encouragement to study from both their mothers and fathers; while $50 \%, 47 \%$ and $43 \%$ received encouragement from sisters, brothers, or another relative, respectively. At the same time, they reported knowing of other young Bedouin women who wanted to study but did not because their parents $(66 \%)$ or their brothers (46\%) were opposed to it.

In all eight interviews, nuclear family support for the daughters' higher education came from both parents, and was more important than the opposition of other family members, most commonly, brothers. Most of the women told stories of brothers who didn't do well in school, and who for either academic or economic reasons, did not go on to higher education themselves. On the one level, they represented negative models for educational attainment, but their influence or even active opposition did not seem to reduce their sisters' determination to go to the university. On another level, the women with younger brothers felt a special responsibility to serve as a source of motivation and encouragement for them to obtain higher education. 
There was a great deal of variation in the role of the extended family among the interviewees. For some, it was supportive of their quest for higher education; while for others, it was not mentioned, suggesting that it did not play a role of any significance at all in their decision to attend the university. Some students discussed the concern of their extended families for upholding Bedouin traditions:

Sahar - Living in an unrecognized village [which has no paved roads or public transportation] creates a lot of additional obstacles. People in my extended family are very critical of my coming home late at night by myself.

While confronted with conflicting values and traditions, several of the interviewees discussed their impact, as role models, on community attitudes and the opportunities for other Bedouin women to pursue higher education. They were acutely aware that their impact could be either positive or negative, depending upon how they walked the tightrope of reconciling traditional values and customs with their pursuit of higher education. As Nadia said:

We women who have made it to the university have to encourage other young women and provide them with an example. If we study and set a good example by developing ourselves, while at the same time maintaining our values, it will open the path for other young women.

\subsection{Islam and Bedouin women's education}

Over $80 \%$ of the students surveyed identified as faithful Muslims who supported Islamic values. Furthermore, the interviewees viewed Islam as a force that supported their right to obtain education, including higher education. As Nadia explained:

"Islam gives a woman many rights, and one of them is the right to study. The Koran says that every person, and specifies male and female, is required - required - to study. Islam doesn't want people to be narrow-minded and undeveloped, but rather to be developed to their fullest potential. In Islam, the woman is very important because she is the basis of the family, and thus, the basis of society. She can't fulfill this important role if she is not educated. She must be educated to be able to create a thriving educational environment in the home and to raise her children to serve their society.”

Several of the women discussed the phenomenon in their community of invoking Islamic principles as a basis for not allowing girls to pursue education, but they asserted that this was an illegitimate distortion of Islamic teachings. They instead identified the Bedouin community's traditions and customs as the actual source of opposition to female education in their society.
Sara - People who say that [Islam is opposed to female education] aren't interpreting Islam correctly; they are interpreting it according to their own interests. And that's what people like to do with religion - just pick out what is in their own interest to emphasize.... Islam doesn't forbid women from becoming educated. It is a religion of “conviction, not coercion."

Interestingly, the interviewees were not persuaded by the negative arguments of local religious leaders, but were secure enough in their own knowledge/interpretation of Islam to challenge and contradict these leaders.

\subsection{Economic influences \& higher education}

The discussion of higher educational opportunities for Bedouin women cannot be isolated from the economic realities of the Negev Bedouin community, given its low socio-economic status. The importance of this dynamic was reflected by the survey findings indicating that that $65 \%$ of the women were generally worried and another 19\% were sometimes worried about financial difficulties, totaling $86 \%$ of the students surveyed. The in-depth interviews provided further insights into the financial constraints with which many in the Bedouin community were struggling, their impact on Bedouin women in particular, and the crucial importance of financial support as a facilitator of women's higher educational opportunities.

Mona - The boys stop studying, and they start working, to bring in money for the family or to make money for themselves so they can study, because neither they nor their families can support their studies without them working.

If families don't have money, they won't send girls to study.

Other students spoke of the many female peers they knew who did not go on to higher education because their families lacked the financial resources.

Rawda - "If I didn't have the financial support from the university, my brother would have supported me. But the year after I started studying, my sister also started, so that's 20,000 NIS a year just for tuition, not counting books, travel, meals, and all of the other expenses. Because the money didn't have to come from my family, it was psychologically much easier for me to study. I wasn't comfortable having to take money from my brother and his family; I would much rather have taken it from my father, but he is unemployed, and he would not have been able to support me and my sister at the university.

The financial support is essential for the female Bedouin students. I know a student in a family with 8 children who got a tuition scholarship her first year, and was denied a scholarship her second year. Her father said that he didn't have the money 
to keep her in school, so she would have to drop out. But she wrote a letter of appeal to the Dean of Students and got the scholarship in the end, and that's the only thing that enabled her to continue her studies.

Scholarship support was essential to relieving female students' psychological pressures, and for many made the different between staying in school or having to drop out.

\subsection{Identity issues}

As part of the Palestinian Arab minority in Israel, Bedouin women must contend with multiple identities, some of which are a source of identity conflict. Most of the students surveyed found ways to integrate the components of being a Muslim, a Palestinian Arab, and an educated woman. As Figure 2 illustrates, most women identified simultaneously as Muslims (92\%), academic degree holders (83\%), and part of the Arab world (79\%). They were much less likely to identify as Bedouin (39\%), or Israeli citizens (12\%).

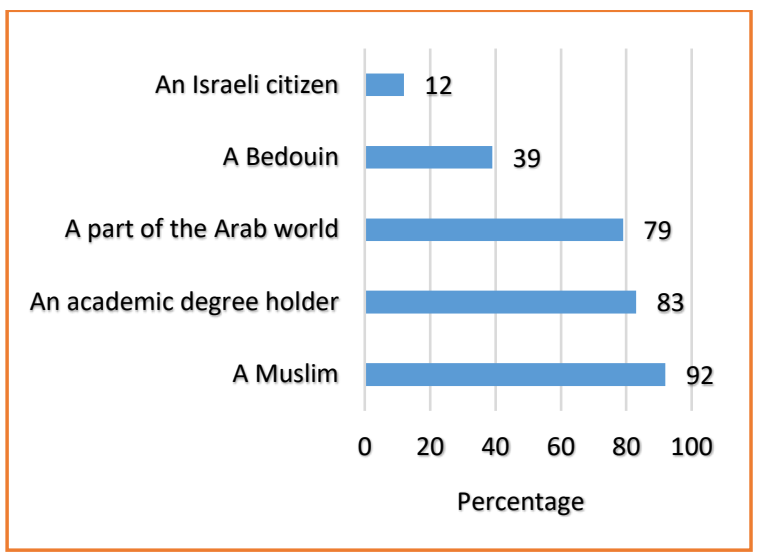

Figure 2: Female Bedouin University Students' Characterization of Their Dominant Identity

In the survey, the female Bedouin students were also asked to rank their preferences for a range of collective national statuses that have been used in other identity studies of the Arab minority in Israel $[18,19,20]$, and the results are summarized in Figure 3. The most popular status was to be part of a secular country in which Arabs and Jews enjoyed equal rights (75\%), followed by being citizens of a binational state (65\%), and being part of a Palestinian state next to Israel (55\%). The least popular status was to live in Israel as a separate group with minority rights (15\%).

The in-depth interviews shed insight into the reasoning behind these social and national identity choices, and on how the women's experiences at the university further shaped their identities.
Figure 3: Female Bedouin University Students' Choice of Preferred National Identity

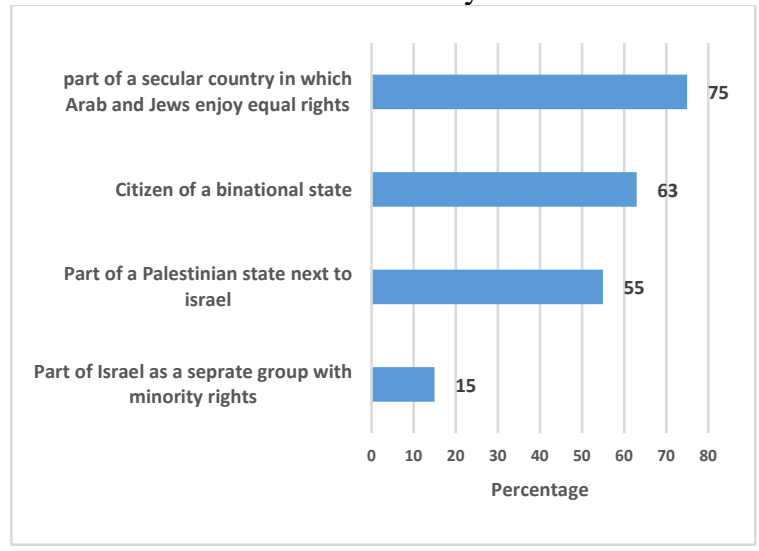

The vast majority (83\%) indicated that being highly educated was important to their identities. This is a somewhat less common way of speaking of identity or defining one's identity, however, material from the interviews demonstrated that the women felt that obtaining a university education had fostered their personal and social development and had had a significant impact on whom and what they became. As Yasmin indicated:

The university is a place that really strengthens and expands your personality. It is a place where your character develops a lot socially and in many ways. You have to learn to decide for yourself, and take responsibility for your own decisions. You have to think about what kind of relationships you want to establish, and think twice before you speak, because you are deciding on your own actions, and you will be responsible for them. You feel proud of yourself when you are studying at the university, not only because of the academic achievement, but also because of the social development.

Furthermore, by providing them with marketable skills, higher education gave them a professional/ career identity. It also empowered them socially and economically, and shaped the ways in which they related to their own society, as well as to mainstream Israeli society. Thus, in these indirect, yet very practical ways, being highly educated was of central importance to the identities of the female Bedouin university students.

Most of the other identity choices were also discussed in the in-depth interviews. Similar to $92 \%$ of the women surveyed, Nadia chose being a Muslim as her dominant identity, and explained her rationale as follows:

"If you asked me this question my first year, I might not have been very sure of myself, and might have vacillated between Arab and Palestinian and Muslim. Now it is very clear to me that I am a Muslim, period. The Arab identity is not important to me; the Palestinian identity is 
important, but less so than my Muslim identity. This is the term that most fully defines who I am. If I identify myself only as an Arab, that could be racist. If I am a Muslim, it means that I am tolerant and forgiving. If I can only identify as an Arab, what does that really mean for me? Arabs had a very flawed society before the coming of Islam, in which women really suffered. Islam changed that. Islam respected me as a woman, and gave me my status. The Qu'ran says, "Heaven lies beneath the feet of the mothers", which places mothers above heaven even. If your goal is to reach heaven, the way to reach it is by respecting your mother as you should. The prophet Muhammad said that the greatest act of charity in the world is for a husband to place a morsel of food in his wife's mouth. Now, if we see a scene like that in a Western movie, where a man places a choice piece of food on his fork, and then feeds it to his wife, we say, "oh, how romantic!" But this is really an image or an idea that actually came from Islam over 1000 years ago. If I just identify as an Arab, it limits me to a specific ethnic and social group. Islam is what gives me my value as a human being and a woman”.

Interestingly, Nadia found in Islam a more universal identity than either her Arab or Palestinian identities provided her with.

Rawda found that, contrary to her expectations, her university experience reinforced her primary identity as Palestinian Arab, while failing to provide her with a collective Israeli identity to which she could belong:

I define myself first as a Palestinian Arab.... My university experience has actually confirmed this, and made it stronger. When I first came to the university, I was really looking forward setting aside politics and the political things that divide us, and interacting with the Jewish students. I wanted to mix with them and learn from them in terms of language and many other things. But I really found that they held themselves apart, so our social interaction remained very superficial. This strengthened my feelings of being different and of belonging to a different people”.

Nura also considered her primary identity to be Palestinian Arab, while she considered the term 'Bedouin' to describe a lifestyle, rather than an identity:

If I am asked, I say that I am a Palestinian Arab. 'Bedouin' is a way of life; it's not a national or ethnic identity. My understanding of my identity hasn't changed because of my studies. I'm secure in my identity, and if it is respected, I can do anything. But it is not always easy. My university experience has strengthened my sense of identity because I'm looked at in a discriminatory way. For example, when we Arabs come in the university gate, the security guard will search our bags very carefully, after we've seen 20 Jewish students go in ahead of us, and guard doesn't search their bags at all. I didn't let this affect me though; I would just let him search. I will prove myself by succeeding at the university. Confronting the security guards would only make problems, because they might open a file on you then in the university security office.

Like most of the other women, Nura did not feel that her university experience changed the identityunderstanding with which she had come to the university. Instead, if anything, the experience of being treated differently than her Jewish counterparts strengthened it. She adopted a practical approach to dealing with discriminatory treatment. For example, rather than fighting the reality that she was viewed and treated differently by the security guards, she chose to prove herself by succeeding in her studies.

\section{Conclusions}

Indigenous Bedouin Arab women in mainstream higher education demonstrated resilience and agency as participants in modernizing Bedouin traditions, and indigenizing 'Western-style' modernity. Despite the challenges it presented, they experienced mainstream higher education as an essential avenue for their personal and communal development.

The women in this study exhibited a consciousness of the need to combine change with continuity by maintaining their core values as they pursued their studies, if they were to effectively expand the opportunities for higher education to other young Bedouin women. Contrary to Western stereotypes (and some local interpretations) of Islam, they viewed Islam as a force that supported their right to obtain education, including higher education. Lack of financial resources in the family, however, represented a prohibitive barrier to higher education for Bedouin women in particular, if outside sources of support could not be found. Other physical barriers that affected attitudes toward higher educational opportunities for Bedouin women in the unrecognized Bedouin villages in particular, though not exclusively, included lack of public transportation and infrastructure (e.g., paved roads, mains electricity, etc.). Individual-level dynamics also played a role in shaping educational opportunities. The stories of these young women exhibited exemplary personal motivation and determination to obtain higher education. Notwithstanding all of the important external influences, they acknowledged their own agency, and their power - as well as responsibility to exercise their personal motivation to reshape attitudes and traditions and create new opportunities for the higher education of women in their community.

Finally, we examined the question of identity among female Bedouin university students. They 
contended with multiple identities, some of which were easily reconciled with the others, and some of which were a source of identity conflict. Most of the women surveyed readily integrated the identity components of Muslim-ness, educated-ness, and Arab-ness. Fewer women considered their Bedouinness to be an important identity component. Likewise, fewer women considered their Israeli-ness an important identity component. As the in-depth interviews revealed, this grew from a sense of marginality due to their status as members of a minority group in a Jewish state. The sense of marginality was conveyed not only by official public discourse and policy, but also, for some, by their intergroup interactions at the university.

Our exploration of the university experience of female Bedouin students showed that it was permeated with struggle on many levels, including: adjusting academically and socially; developing essential functional skills in Hebrew and English; obtaining academic assistance; financial constraints; and, identity politics, along with majority stereotypes of "the Bedouin woman". They demonstrated great persistence, determination and resourcefulness in coming up with coping strategies for these problems.

In conclusion, the study findings provide insight into the complexity, variation, and dynamic nature of the Bedouin community as the role of Bedouin women is evolving. The female Bedouin university students who participated in the study confronted and sought to break down the static, one-dimensional stereotypes of Bedouin women and society. They represent the embodiment of real empowerment for Bedouin women, which will come through tangible means. First among these is obtaining higher education and the skills needed to restore the social and economic role of Bedouin women in their community, and facilitate their integration into the modern Israeli labor market. They will then be equipped to take a leading role in their individuallevel and community-level development, and in responding to the changing demands and opportunities of the $21^{\text {st }}$ century.

\section{References}

[1] Turner, M., Shweiki, O., (2014). (Eds.), Decolonizing Palestinian Political Economy, Palgrave Macmillian, London, pp. 135-157.

[2] Abu-Saad, I., (2016). “Access to Higher Education and its Socio-Economic Impact among Bedouin Arabs in Southern Israel”, International Journal of Educational Research, Vol. 76, pp. 96-103.

[3] Abu-Saad, K., Horowitz, H., Abu-Saad, I., (2011). Weaving Tradition and Modernity: Bedouin Women in Higher Education. Ben-Gurion University of the Negev Press, Beer-Sheva.
[4] I. Abu-Saad, "Bedouin Arabs in Israel: Education, political control and social change”. In C. Dyer (Ed.) The Education of Nomadic Peoples: Issues, Provision and Prospects. Oxford: Berghahn Publishers, 2006, pp. 141158.

[5] Abu-Saad, I., Abu-Saad, K., Hundt, G., Forman, M.R., Belmaker, I., Berendes, H., \& Chang, D., (1998). "Bedouin Arab mothers' aspirations for their children's education in the context of radical social change", International Journal of Educational Development, 1998, Vol. 18: 347-359.

[6] Swirski, S., (1990). Education in Israel: Schooling for Inequality. Brirot, Tel Aviv, (in Hebrew).

[7] Antoun, R., (1968). "On the modesty of women in Arab Muslim villages: A study in the accommodation of tradition”, American Anthropologist, Vol. 70(1), pp. 671697.

[8] Mandelbaum, D., (1988). Women's Seclusion and Men's Honor, University of Arizona Press, Tucson.

[9] Mazumdar S. \& Mazumdar S. "Rethinking public and private space: Religion and women in Muslim society", Journal of Architectural and Planning Research, 2001, Vol. 18(4), pp. 302-324.

[10] E. Shakir, Bint Arab: Arab and Arab American Women in the United States, Praeger, Westport, Connecticut, 1997.

[11] Read, J., (2002). "Challenging myths of Muslim women: The influence of Islam on Arab-American women's labor force activity”, The Muslim World, Vol. 92, pp. 19-38.

[12] Waheb, A., (1997). "Splitting identities: The gap between real and ideal on the status of women in Islam", Journal of Islamic Guidance, 1997, Vol. 1(3), pp. 3-7.

[13] Badawi, J., (1980). The Status of Women in Islam, 1980,http://www.jannah.org/sisters/badawistatus.pdf.

(Access date: 7 November 2017).

[14] Qur’an, Al-Nisaa, 4:7.

[15] Ragab, A., (1995). Middle East and Egypt. In T. D. Watts, D. Elliott \& N. Mayadas (Eds.) International Handbook on Social Work Education, Greenwood Press, London, pp. 281-304.

[16] Hassan, R., (1995). "From re-active to pro-active - The challenge for Muslim women on the road from Cairo to Beijing”, Paper presented at the IPPF Inter-Regional Workshop on 'Women in Islam: Human Rights and Family Planning', Tunis, July. URL: http://www.hartfordhwp.com/archives/28/009.html.

[17] Keddie, A., (2006). "Negotiating and enabling spaces for gender justice”, Issues in Educational Research, Vol, 16, pp. 21-37.

[18] Abu-Saad, I., Yonah, Y., Kaplan A., (2000), “Identity and Political Stability in an Ethnically Diverse State: A Study of Bedouin Arab Youth in Israel”, Social Identities, Vol. 6(1): 49-61. 
[19] Smooha, S., (1984). The Orientation and Politicization of the Arab Minority in Israel, Monograph Series on the Middle East No. 2, Institute of Middle Eastern, Haifa, 1984.

[20] Smooha, S., (1995). "Arab-Jewish relations in Israel in the peace era”, Hamizrah Hehadash, Vol. XXXVII: 64-78 (in Hebrew). 